\title{
Effect of Flavouring Agent on Ice Cream Quality
}

\author{
Manik Eirry Sawitri $^{1 *}$, Umi Wisaptiningsih $^{2}$, Abdul Manab $^{1}$ and Ria Dewi Andriani ${ }^{1}$ \\ ${ }^{1}$ Department of Animal Food Technology, ${ }^{2}$ Department of Social Economic, Faculty of Animal \\ Husbandry, Brawijaya University Malang, East Java, Indonesia \\ *Corresponding author
}

\section{Keywords \\ Ice cream, Flavouring, Composition, Melting, Overun, Microbial. \\ Article Info \\ Accepted: \\ xx September 2017 \\ Available Online: \\ xx November 2017}

\section{A B S T R A C T}

The effect of different flavourings on ice cream quality was observed. Ice cream flavoured with synthesized vanilla, strawberry, and chocholate flavours, were compared for proximate (protein, fat, sugar and moisture content), physical properties (overrun, melting rate), heavy metal ( $\mathrm{Pb}$ and $\mathrm{As}$ ) and $\mathrm{APC}$. The protein content of vanilla, strawberry and chocholate ice cream were $4.063,4.110$, and 4.197 respectively. The fat content of vanilla, strawberry and chocholate ice cream were $12.395,12.397$ and 13.199 respectively. The sugar content of vanilla, strawberry and chocholate ice cream were 20.750, 21.516 and 23.511 respectively. The moisture content of vanilla, strawberry and chocholate ice cream were $37.512,37.793$ and 38.724 respectively. The $\mathrm{Pb}$ content of vanilla, strawberry and chocholate ice cream was $0.009,0.008$ and 0.009 respectively. The As content of vanilla, strawberry and chocholate ice cream were $0.001,0.001$ and 0.001 respectively. The aerobic plate count (APC) of vanilla, strawberry and chocholate ice cream was 0.741 , 0.499 and 0.944 respectively. The melting rate of vanilla, strawberry and chocholate ice cream was $30.30,30.30$ and 30.33 respectively. The overrun of vanilla, strawberry and chocholate ice cream were $42.66,48.28$ and 45.60 respectively. The protein, fat, sugar, moisture content, overrun and APC of chocholate ice cream were higher than vanilla and strawberry ice cream, however the melting rate and heavy metal ( $\mathrm{Pb}$ and $\mathrm{As}$ ) content were similar. The results demonstrated that flavouring agent used in the ice cream produce slight different in chemical composition, overrun and total microorganism of ice cream, however similar in melting and heavy metal ( $\mathrm{Pb}$ and $\mathrm{As})$ content.

\section{Introduction}

Ice cream is a dairy product that obtained through ice cream mix freezing (Deosarkar et al., 2016). Ice cream consists of milk, milk solids not fat, sugars, emulsifying agent, stabilizing agent, fat, and flavor agent that mixed together to form the ice cream mix, which is then frozen for incorporate air and blast freezing for hardening (Clarke, 2012). Ice cream contains solid (in the ice crystals and fat globules), liquid (in the sugar solution), and gas (in the air bubbles). Several efforts have been devoted to exploiting flavouring ice cream because flavours are very important in food appreciation (Visser and Thomas, 1987). It is a complex of sensations of taste and smell derived from food (Ihekoronye and Ngoddy, 1985). Ice cream flavour is very important in the judgment of the consumer and in this respect (Iwe, 2003). There is need to improve ice 
cream odours by subjecting the products to different flavours. The use of different flavourings in ice cream has been attempted increasingly.

A relatively low storage temperature and pasteurization step during ice cream processing are considered to eliminate most of microorganisms. However, improper handling and storage temperatures, raw materials of ice-cream mix (Gomez, 1999) especially flavor addition are factors that contribute to the potential hazard especially after pasteurization processes. Therefore, there is a need to maintain a high quality, microbiological safe standard (Champagne et al., 1994) and physical properties of oce cream. Overrun and melting rate of ice cream are important properties for quality evaluation (Arbuckle, 1986). The aim of this research is to determine compositional, physichal properties and bacteriological quality of flavoured ice cream.

\section{Materials and Methods}

\section{Ingredients}

Milk solid non fat, fat, sugar, emulsifying agent, stabilizing agent, flavouring agent (vanilla, strawberry and chocholate).

\section{Ice cream compositional analyses}

The proximate analysis of ice cream were crude protein content, moisture content, fat content, and sugar content (AOAC, 1985).

\section{Microbiological analysis}

One gram of ice cream mixture was aseptically tranfered into $9 \mathrm{ml}$ sterile pepton water and serial dilutions was made to make $10^{-3}$ dilution. Growth media was prepared according to specifications on the containers. Total viable counts was determined by the methods described by Adegoke (2000).

\section{Melting characteristic}

$100 \mathrm{~g}$ of ice cream were placed on a wire screen fitted in a funnel and allowed to melting at $25 \pm 0.5^{\circ} \mathrm{C}$. The volume of melted ice cream was observed at 5-minute intervals (Innocente et al., 2002)..

\section{Overrun determination}

Ice milk overrun was determinated using a $100 \mathrm{ml}$ cup (Arbuckle, 1986) based on the following equation:

Overrun $(\%)=[($ Netto weight of cup of mix netto weight of cup of ice milk)/ Netto weight of cup of ice milk] $\times 100$

\section{Statistical analysis}

The data was analysed using analysis of variance (ANOVA) using software in order to evaluate the influence of flavouring agent on ice cream quality.

\section{Results and Discussion}

\section{Composition of ice cream}

The composition of flavoured ice cream show the chemical composition of ice cream made by different flavouring agent (Table 1). The protein content of vanilla, strawberry and chocholate ice cream were 4.063, 4.110, and 4.197 respectively. The fat content of vanilla, strawberry and chocholate ice cream were $12.395,12.397$ and 13.199 respectively. The sugar content of vanilla, strawberry and chocholate ice cream were 20.750, 21.516 and 23.511 respectively. The moisture content of vanilla, strawberry and chocholate ice cream were $37.512,37.793$ and 38.724 respectively. The nutritional value of ice cream was not significant, this is due to the kind of ingredients used in their preparation (milk, milk fat, water, sugar, flavorings and sta- 
bilizers) were similar. Fat, protein, moisture and sugar content were slight higher in choocholate flavor that vanilla and strawberry ice cream.

According to the Indonesia National Standard, the composition of ice cream should exceed 2.7, 5 an $8 \%$ for protein, fat and sugar content, respectively.

\section{Physical properties}

The physical properties of flavoured ice cream given in Table 2 that show the meltability and overrun of ice cream made by different flavouring agent. The melting of vanilla, strawberry and chocholate ice cream were $30.30,30.30$ and 30.33 respectively. The overrun of vanilla, strawberry and chocholate ice cream were 42.66, 48.28 and 45.60 respectively. The highest overrun were obtained from ice cream made strawberry, while the lowest were obtained in ice cream made vanilla. The meltability of all flavours of the ice cream samples tested were similar.

Air content and the dispersed air cell size are important in the overrun measurement (Javidi et al., 2016). Proteins, fat, emulsifier and stabilizer are important in air incorporation and stabilization of air cells (Marshall et $a l ., 2003)$. If icm viscosity is not very high, the film that coat air bubbles and the bubbles coalesce (Clarke, 2004).

On the other hand, if icm viscosity is very high may prevent incorporation of air (Bahram Parvar et al., 2013).

Table.1 The composition of flavoured ice cream

\begin{tabular}{|c|c|c|c|c|}
\hline $\begin{array}{l}\text { Flavoured ice } \\
\text { cream }\end{array}$ & $\begin{array}{c}\text { Protein content } \\
(\%)\end{array}$ & $\begin{array}{c}\text { Fat content } \\
(\%)\end{array}$ & $\begin{array}{c}\text { Sugar content } \\
(\%)\end{array}$ & $\begin{array}{c}\text { Water content } \\
(\%)\end{array}$ \\
\hline Vanilla & $4.063^{\mathrm{a}}$ & $12.395^{\mathrm{a}}$ & $20.750^{\mathrm{a}}$ & $37.512^{\mathrm{a}}$ \\
\hline Strawberry & $4.110^{\mathrm{a}}$ & $12.397^{\mathrm{a}}$ & $21.516^{\mathrm{a}}$ & $37.793^{\mathrm{a}}$ \\
\hline chocholate & $4.197^{\mathrm{a}}$ & $13.199^{\mathrm{a}}$ & $23.511^{\mathrm{a}}$ & $38.724^{\mathrm{a}}$ \\
\hline
\end{tabular}

Table.2 Physical properties of flavoured ice cream

\begin{tabular}{|c|c|c|}
\hline $\begin{array}{l}\text { Flavoured ice } \\
\text { cream }\end{array}$ & $\begin{array}{c}\text { Meltability } \\
\text { (minutes) }\end{array}$ & Overrun (\%) \\
\hline Vanilla & $30.300^{\mathrm{a}}$ & $42.665^{\mathrm{a}}$ \\
\hline Strawberry & $30.303^{\mathrm{a}}$ & $48.279^{\mathrm{a}}$ \\
\hline chocholate & $30.337^{\mathrm{a}}$ & $45.599^{\mathrm{a}}$ \\
\hline
\end{tabular}

Table.3 The heavy metal content of flavoured ice cream

\begin{tabular}{|c|c|c|}
\hline $\begin{array}{l}\text { Flavoured ice } \\
\text { cream }\end{array}$ & $\mathrm{Pb}(\mathrm{mg} / \mathrm{kg})$ & $\mathrm{As}(\mathrm{mg} / \mathrm{kg})$ \\
\hline Vanilla & $0.009^{\mathrm{a}}$ & $0.001^{\mathrm{a}}$ \\
\hline Strawberry & $0.008^{\mathrm{a}}$ & $0.001^{\mathrm{a}}$ \\
\hline chocholate & $0.009^{\mathrm{a}}$ & $0.001^{\mathrm{a}}$ \\
\hline
\end{tabular}


Table.4 Aerobic plate count (APC, log CFU/g) of flavoured ice cream

\begin{tabular}{|c|c|}
\hline Flavoured ice cream & APC \\
\hline Vanilla & $0.741^{\mathrm{a}}$ \\
\hline Strawberry & $0.499^{\mathrm{a}}$ \\
\hline Chocholate & $0.994^{\mathrm{a}}$ \\
\hline
\end{tabular}

The physical properties (overrun and melting rate) depends on the ingredient of the ice cream mix. An elevated fat coalesced can increase ice cream overrun, because more fat to trap air bubbles (Abd El-Rahman et al., 1997). Fat agglomeration reduced melting rate of ice cream (Schmidt, 2004). Emulsification ability of milk proteins can alter aircell interfaces of ice cream (Barfod et al., 1991; Schmidt, 2004). The melting rate of ice cream is affected by several factors, including icm ingredients, air incorporated amount, the properties of the ice crystals, and the fat globules network that formed during ice creaming freezing (Bahram Parvarand et al., 2011; Muse and Hartel, 2004).

\section{Heavy metal content}

The heavy metal content of flavoured ice cream given in Table 3 that shows the heavy metal content in ice cream made by different flavouring agent. The $\mathrm{Pb}$ content of vanilla, strawberry and chocholate ice cream were $0.009,0.008$ and 0.009 respectively. The As content of vanilla, strawberry and chocholate ice cream were $0.001,0.001$ and 0.001 respectively. The average numbers of the heavy metal content $(\mathrm{Pb}$ and $\mathrm{As})$ were obtained from ice cream made vanilla, Strawberry and chocholate were similar. According to the Indonesia National Standard, $\mathrm{Pb}$ and $\mathrm{As}$ of ice cream should not exceed 1.0 and $0.5 \mathrm{mg} / \mathrm{kg}$, respectively.

\section{Aerobic plate count}

The Aerobic Plate Count (APC) of flavoured ice cream given in Table 4 that shows the
APC in ice cream made by different flavouring agent. The highest APC were obtained from ice cream made chocholate, while the lowest were obtained in ice cream made strawberry. Aerobic plate count (APC) is one of the microbiological hazards in ice cream, several factors can lead to their proliferation in ice cream. According to the Indonesia National Standard, APC of ice cream should not exceed $2 \times 10^{5} \mathrm{CFU} / \mathrm{g}$.

The results in the chemical composition of ice cream made by different flavouring agent was not significant. Fat, protein, moisture and sugar content were highest in chocholate flavor ice cream. The heavy metal content in ice cream made by different flavouring agent were similar. The total microbial count in ice cream made by chocholate was highest, while the lowest minimum average was obtained in ice cream made strawberry.

\section{Acknowledgment}

This work was supported by the Ministry of Research and Technology, Directorate General of Higher Education, Republic of Indonesia.

\section{References}

Abd El-Rahman, A. M., Madkor, S. A., Ibrahim, F. S., and Kilara, A. 1997. Physical characteristics of frozen desserts made with cream, anhydrous milk fat, or milk fat fractions. Journal of Dairy Science, 80(9), 1926-1935.

Adegoke, G.O. 2000. Understanding Food Microbiology(Shalom Press, Ibadan, 
Nigeria: 129-191.

AOAC. 1985. Official Method of Analysis, Association of Official Analytical Chemist, Washington DC.

Arbuckle, W. S. 1986. Ice cream. AVI Publ. Co., Inc.,

Bahram Parvar, M. and Mazaheri Tehrani, M. 2011. Application and functions of stabilizers in ice cream. Food Reviews International, 27(4), 389-407.

Bahram Parvar, M., and Goff, H. D. 2013. Basil seed gum as a novel stabilizer for structure formation and reduction of ice recrystallization in ice cream. Dairy Science \& Technology, 93, 273e285.

Barfod, N. M., Krog, N., Larsen, G., and Buchheim, W. 1991. Effects of emulsions on protein-fat interaction in ice cream nix during ageing. Quantitative analysis. Fat Science Technology, $93: 24-29$.

Champagne, C.P., Laing R.R., Roy D., and Mafu A.A. 1994. Psycrotrophs in dairy products: Their effects and their control. Crit. Rev. Food Sci. Nutr., 34: 1-30.

Clarke, C. 2012. The Science of Ice Cream. Cambridge: Royal Society of Chemistry Publishing.

Deosarkar, S. S., Kalyankar, S. D., Pawshe, R. D., and Khedkar, C. D. 2016. Ice cream: Composition and health effects. reference module in food science, from encyclopedia of food and health. 385390

Gomez, A. 1999. Microbial content and hygienic conditions of ice- cream sold in Leon Alimentonia 6: 21-25.
Ihekoronye, A.I. and Ngoddy, P.O. 1985. Integrated Food Science and Technology for the Tropics (London and Basingstoke: Macmillian Publishers).

Innocente, N., Comparin, D. and Corradini, C. 2002. Proteose-peptone whey fraction as emulsifier in ice-cream preparation. Int. Dairy J., 12(1): 69-74.

Iwe, M.O. 2003. The science and technology of soybean: chemistry, nutrition, processing, and utilization (Enugu, Nigeria, Rejoint Communications Services Ltd). Pp 1-286.

Javidi F., Razavi, S.M.A. Behrouzian, F., Alghooneh, A. 2016. The influence of basil seed gum, guar gum and their blend on the rheological, physical and sensory properties of low fat ice cream. Food Hydrocolloids, 52: 625-633.

Marshall, R. T., Goff, H. D., and Hartel, R. W. 2003. Ice cream (3rd ed.). New York: Aspen Publishers.

Muse, M.R. and Hartel, R.W. 2004. Ice cream structural elements that affect melting rate and hardness. Journal of Dairy Science, 87, 1-10.

Schmidt, K. A. 2004. Dairy: Ice cream. Food processing - Principles and applications (pp. 287-296). Ames, IA: Blackwell Publishing.

Visser, A. and Thomas, A. 1987. Review: Soya Protein Products, their Processing, Functionality, and Application Aspects. Food Reviews Int'1., 31 (182): 1-32.

\section{How to cite this article:}

Manik Eirry Sawitri, Umi Wisaptiningsih, Abdul Manab and Ria Dewi Andriani. 2017. Effect of Flavouring Agent on Ice Cream Quality. Int.J.Curr.Microbiol.App.Sci. 6(11): 4196-4200. doi: https://doi.org/10.20546/ijcmas.2017.611.491 